Zabytkoznawstwo i Konserwatorstwo XLIII, Torun 2012

\title{
Mirosław Wachowiak
}

Zakład Konserwacji i Restauracji Sztuki Nowoczesnej

Instytut Zabytkoznawstwa i Konserwatorstwa, WSzP UMK

\section{Kilka uwag \\ na temat sygnatur obrazów olejnych Józefa Pankiewicza}

ankiewicz podpisał znakomitą większość swoich obrazów. $\mathrm{Na} 362$
wzięte pod uwagę obrazy, tylko $3,5 \%$ nie posiada sygnatury (te nieliczne przypadki pochodza głównie z lat 1908-1910, oraz z okresu hiszpańskiego). W jednym tylko przypadku pojawia się dedykacja na licu (dla Feliksa Jasieńskiego), czasem pojawiaja się raczej dość lakoniczne (np. określające miejsce lub/i czas powstania) inskrypcje na odwrociu, zwłaszcza malowideł na tekturze oraz desce. Artysta nie miał „ulubionego” dolnego narożnika dla umieszczania podpisu. Statystyka wykazuje doskonałą wprost równowagę - po 38\% przypadków dla lewego i prawego narożnika. Potwierdza to zasadniczo dużą swobodę artysty w podejściu do sygnatury i dostosowywania jej do obrazu - jego kompozycji i kolorystyki, o czym świadcza choćby nieliczne przypadki umieszczania sygnatury w połowie wysokości obrazu np. poziomo na granicy obrusa w martwych naturach z kwiatami, czy cały przekrój kolorów stosowanych dla podpisów, zwłaszcza w barwnym okresie hiszpańskim i krótko po nim (fiolet, czerwień), podczas gdy w okresie impresjonistycznym dominował błękit. Również w samym sposobie pisania, widoczna jest duża dowolność i zmienność. Mimo możliwości wydzielenia kilku okresów o sygnaturze zbliżonej charakterem liternictwa, dotyczy to jednak cech głównych, a podpis w szczegółach często się różni. O potrzebie ostrożności o orzekaniu np. z jakiego okresu pochodzi obraz 
na podstawie charakteru podpisu, świadczyć moga obrazy sygnowane podwójnie - często w odmienny zupełnie sposób (jak w przypadku Portretu Józefy Oderfeld (Portret dziewcrynki w czerwonej sukni, 1897, MNKi, fot. 8, 9), czy Pejzażu z okolic Kazimierza (1891). Niektóre obrazy na płótnie (Czeszaca sie (1911), a zwłaszcza na tekturze (np. pejzaże morskie z St. Valery z 1907 roku), niewykluczone, że podpisane były piórkiem tuszem lub atramentem. Zasadniczo w podpisie pojawiało się jedynie nazwisko „Pankiewicz”, tylko w nielicznych wczesnych obrazach poprzedzone inicjałem imienia. Rzadko uzupełniane bywało datą roczną (zasadniczo do okresu hiszpańskiego - później już tylko sporadycznie). Formy zapisu daty przybierały postać pełnej daty rocznej lub ostatnich dwóch cyfr, jak np. w kilku obrazach między 1902-1909 (np. „Pankiewicz 02” w Ukryyżowaniu z 1902 roku). W nielicznych przypadkach znajduje się również informacja o miejscu powstania obrazu (Czarnolas, Dubój [fot. 7], Paris, St Valey an Caux).

Na wczesnym obrazie olejnym Pankiewicza Żyd z koszem (1888) sygnatura jest jeszcze w duchu zupełnie dziewiętnastowiecznym (fot. 1). Wykonana w lewym dolnym rogu, na ciemnym tle, czerwona farba, pisana drukowanymi, hieratycznymi literami, obok nazwiska - zawiera inicjał imienia, oraz skrót daty: ,J. Pankiewicz. 87’. Odcina się ona zupełnie i wyrywa z malarskiego przedstawienia, funkcjonując jak domalowana etykietka, liternictwem bliższa estetyce szyldu, niż odręcznemu podpisowi. Prawdopodobnie taka sama w charakterze sygnatura (a na pewno w treści, patrz katalog) pojawia się na obrazie Sień na Starym Miéscie z roku 1888. Nadal hieratyczny podpis odnajdujemy na przedstawieniu $\mathrm{z}$ tego samego roku Targ na jarayny za Żelazna Brama w Warszawie (fot. 2). Także w tym przypadku pojawia się inicjał oraz skrótowa data: „J. Pankiewicz. 88”. Niemniej zastosowanie dla sygnatury tego samego, co użytego w tym fragmencie obrazu koloru biało-źółto-zielonkawego, oraz małych liter, powoduje, że podpis jest bardziej „włączony” w obraz. Mimo że bardzo uporządkowana, (prawie jak druk, nawet literka „a" pisana jak w druku, a nie w zwykłej formie odręcznej), całość działa już bardziej miękko, co widoczne jest choćby w tak drobnym szczególe jak dwie ósemki, które uzyskały okragłe brzuszki, w przeciwieństwie do ostrych form z pierwszego obrazu. Są one również umieszczone poniżej linii samego odpisu, co stanie się regułą w dalszej twórczości artysty, tam, gdzie zdecydował się na umieszczenie daty. Po- 
cząwszy od pierwszego impresjonistycznego obrazu Targ na Kwiaty przed kościolem Saint Madeleine w Paryżu (1890), pojawia się w sygnaturach kolor niebieski (fot. 3). W charakterze liternictwa można potraktować podpis jako formę przejściową między „drukarskim”, sztywnym traktowaniem, a odręczną stylistyką obrazów kolejnych. Artysta rezygnuje z inicjału, natomiast pełna data roczna jest pisana pod spodem, $\mathrm{z}$ dziewiątką schodząca poniżej linii reszty cyfr. Zupełnie swobodne, w charakterze szybkiego podpisu piórkiem, sa malowane niebieską farbą sygnatury trzech kolejnych obrazów impresjonistycznych: Wóz z zianem (1890), Droga w Kazimierzu nad Wista (1890, fot. 5), oraz pochodzacy z kolejnego roku Pejzaż z okolic Kazimierza. Podpisy są bardzo podobne w charakterze (zwłaszcza w przypadku pierwszego i ostatniego obrazu): malowane cienko farbą schudzoną dużą ilością spoiwa, w identycznym ciemnoniebieskim kolorze, i niewatpliwie zostały naniesione już po całkowitym wyschnięciu warstwy malarskiej. Prawdopodobne, że sygnatury na pierwszym i ostatnim obrazie mogły zostać wykonane w tym samym czasie, a więc nie wcześniej niż w roku 1891. Zastanawia znaczna różnica w charakterze sygnatur dwóch kolejnych impresjonistycznych pejzaży z roku 1890: Lato. Motyw z Kaz̧imierza oraz Każimierz nad Wista. Duże litery drukowane w całym nazwisku („PANKIEWICZ”) malowane kryjąco, pisane sa rozstrzelona, rozchwiana czcionka, a w przypadku obrazu Lato o przerywanej rzeźbą impastu ciagłości linii (fot. 4, takie drukowane rozchwiane litery pojawiaja się również w obrazie Zautek noca. Waski Dunaj z roku kolejnego). Na obrazie Krajobraz z okolic Kazimierza (1891) pojawiają się dwie sygnatury, a na obrazie Portret kobiety (1893), obok malowanego rozcieńczoną niebieską farbą nazwiska pojawia się, prawdopodobnie dopisana później, data w kolorze czarnym. Bliskie sobie w charakterze sa podpisy na obrazie Kamelie na misie (1891), oraz Pejzaż z Czarnolasu (1891), przypominające cienką kreską styl osiagany przez użycie piórka i tuszu. W tak krótkim okresie (1887-1983) pojawia się w sygnaturach artysty duża różnorodność podejścia. Generalizując, można powiedzieć, że zmierzał on od usztywnionej formy liternictwa i niezależnej od obrazu w okresie realistycznym, ku formie bardzo swobodnej i coraz bardziej wpisanej w malarskie przedstawienie lub wobec niego neutralnej w okresie impresjonistycznym.

W latach kolejnych, tak w nokturnach, jak i portretach okresu symbolicznego, litery sa pisane coraz bardziej miękko i dekoracyjnie, niejed- 
nokrotnie z wykwintnymi zawijasami (zwłaszcza w literze „P” oraz „z”). Nie pojawia się już inicjał imienia natomiast, zwłaszcza na portretach z 1897 roku - pełna data roczna, z cyframi 97 umieszczanymi nieco niżej niż cyfra tysiąca i setek (18). W przypadku Parku w Duboju określone jest również miejsce powstania: „Pankiewicz 1897 Dubój”. Charakterystyczne dla portretów z lat 90. wydaje się dawanie dużej ilości „powietrza” modelom w części górnej płótna, i tam umieszczanie sygnatury dla kompozycyjnego zagospodarowania tej przestrzeni. Tak dzieje się w przypadku Portretu Henryka Jasieńskiego (1895), oraz Stefana Polczyńskiego (1897). W przypadku dwóch wersji Portretu Józefy Oderfeld (obydwa obrazy z 1897) podpisy w górnej części obrazu są aktualnie niewidoczne. Artysta pomniejszył rozmiar płótna i obecnie sygnatury znajdują się na zawiniętej pod ramą krajce górnej. W przypadku obrazu z muzeum z Kielc artysta zdecydował się więc na umieszczenie kolejnej sygnatury w prawej dolnej części obrazu, już bez daty (fot. 8, 9), a w wersji z Krakowa, (która według konserwatorów również ma ukrytą na górnej krajce sygnaturę), druga, widoczną umieścił Pankiewicz w prawym górnym rogu.

Na kilku obrazach z lat 1904-1906 (Portret wtasny, (1904, fot. 10) Portal katedry San Marco w Wenecji, (1905), Budda i lewkonie, (1906)), liternictwo zostaje uproszczone, a małych rozmiarów podpis malowany jest czarną farbą drobnymi literami bez żadnych ozdobników.

Od roku 1908 znacznie większa swoboda widoczna w kształtowaniu obrazu, wpływa również na charakter sygnatur. Wraca lekkość odręcznego pisma, zwłaszcza w traktowaniu litery „P'. Pojawia się też charakterystyczna litera „z", pisana podobnie, jak dawniej cyfra 3 , z fantazyjnym zawijasem schodzącym poniżej całego podpisu. Wszystkie podpisy malowane sa czystą czernia lub bardzo ciemnym brązem. Datowanie jeśli się pojawia, to w postaci zera i cyfry („08” - Pejzaż z Bretanii, (1908); „09” - Portret Wojciecha Biesiadeckiego oraz Martwa natura z no:̇em, fot. 11). W przypadku Japonki (wersja z MNK, 1908) pojawia się pełna data roczna pisana pod podpisem, a w Portrecie Felikesa Jasieńskiego (1908), wyjątkowy w twórczości artysty przypadek dedykacji umieszczonej na licu obrazu, również z pełną data („Panu Feliksowi Jasieńskiemu/ pankiewicz 1908", fot. 12). W obydwu obrazach pojawia się po raz pierwszy mała litera „p" w nazwisku, widoczna jeszcze w niektórych obrazach z roku 1909 i 1910. W części obrazów uwidacznia 
się optyczny podział nazwiska na człony „Pan” i „kiewicz” poprzez silne akcentowanie litery „P” oraz wyrazisty pion „,k”. W Anemonach (Martwa natura ze zlotymi rybleami, 1908), oraz w Martwej naturze z taca (1908), podpis wykonany jest rzadką farbą koloru czerwonego, dopełniając wysublimowaną szlachetna gamę kolorystyczną. Na obrazie Goździkiki czerwone (ok. 1910, $\mathrm{MNW}$ ), umieszczone sa jedna nad druga dwie sygnatury podobne w charakterze. Prawdopodobnie jest to autorska poprawka przetartej sygnatury spodniej.

W obrazach z lat 1911-1912 podział nazwiska na człony „Pan” i „kiewicz” się utrzymuje, a ponieważ „p” jest pisane z małej litery nad całościa góruje „k". Litery są bardziej rozchwiane, malowane grubszą linią, i każda oddzielnie. Charakterystyczny zawijas przy „z” pozostaje, ale się upraszcza. Kolor podpisu jest najczęściej zdecydowanie czarny, sporadycznie brąowy (fot. 13).

W hiszpańskim okresie (1914-1919) czystego koloru swobodnie stosowanego w obrazach, Pankiewicz rozciaga tę zasadę również i na sygnaturę malowaną błękitem, fioletem, różem, czerwienią (fot. 14, 15). Litera „P” ponownie zaczyna „dominować” nad podpisem, nawet jeśli pisana jest niżej niż litera „k”. Wyrazisty jest (inaczej niż w latach 1911-1912) „górny ogonek” od brzuszka „P”. Całość jest bardziej swobodna niż w latach poprzedzających, nie dorównuje jednak dezynwolturze z okresu lat 1908-1910. Litery pisane są osobno ze sporym rozstrzałem. W większości przypadków pozostaje „trójkowe” „z”. Często farba w podpisie jest bardzo rozrzedzona, prawie transparentna. W przypadku Domów w Madrycie pojawiają się dwa podpisy, oraz nieobecna na innych obrazach tego okresu data („pankiewicz” oraz „Pankiewicz 1915”). W malowanych w roku 1918 kopiach pojawiają się na licu informacje o pierwowzorach obrazów. W przypadku obrazu Judyta i Holofernes, kopia - „Pankiewicz/ podług Tintoretta/ Prado"; Młodośc miedsy cnota a wystepkiem, kopia - „Pankiewicz/podług Veroneza”; Znalezienie Mojżesza, kopia - „Pankiewicz/ podług Tintoretta/ Prado”.

Po powrocie do Paryża, od 1919 roku generalnie zanika trójkowe „z”. Litery są raczej dość proste i drobne i bez ozdobników, poza wyrazistym zawijasem przy literze „P”, i raczej dość nieśmiałym ogonkiem schodzacym w dół w przypadku litery „z”. Zróżnicowana jest kolorystyka (błękity, czerwienie, brązy, czernie) oraz grubość linii. Nierzadkie jest użycie zupeł- 
nie transparentnej farby (fot. 16), często dopasowywanej w kolorze do barwnych w tym okresie przedstawień, zwłaszcza w przypadku martwych natur (np. Anemony w dz̧banku, ok. 1921, fot. 17).Od roku 1923 narasta powtórnie dekoracyjne traktowanie liter, zwłaszcza „P” z zawijasami, a w niektórych przypadkach również litery „k”. Zasadniczo obrazy sygnuje tylko nazwisko (wyjątkiem jest obraz Akt na kanapie z różowa poduszka, 1925: „Pankiewicz Paris/1923", fot. 18), a używany do podpisu kolor to czerń lub brąz (zdarzaja się pojedyncze przykłady innych kolorów jak np. czerwień w sygnaturze obrazu Bryoskwinie, melon $i$ banany, (1924)). Z powtórnym autorskim dodaniem drugiej sygnatury, po uprzednim niedokładnym zamalowaniu pierwszej, mamy do czynienia w obrazie Akt kobiety siedzacej, (1925) („Pankiewicz”, fot. 20).

Zasadniczo artysta malował ciemny podpis na jaśniejszym tle. Nieliczne wyjątki to Labedzie noca (1893-1894, biało-zółty na zieleni); Wnetręe katedry w Chartres (1903) (źółcień na brązie) Budda i gałazka mimoðy (1906-1908, żółcień na czarno-zielonym), Pejzaż z Saint-Tropez - Pinie, 1921 (żółty na ciemnozielonym, fot. 21), Bukiet tulipany, anemony $i$ irysy w porcelanowym wazonie, ok. 1929 (żółcień na brązie), Freajje $i$ anemony w šklanym flakonie, 1930 (żółcień na brązie).

Niektóre podpisy np. w obrazach Sqkic do wnetrza katedry w Chartres (1903), Wejscie do portu w San Valery an Caux I i II, (1907), Czzeszaca sie (1911), sa w charakterze pisma piórkiem i nie wykluczone, że zostały dodane później. Na kilku dziełach znajdujemy adnotacje na odwrociu, najczęściej dotyczące czasu i miejsca powstania obrazów. Na odwrociu Szkicu do Portalu katedry w Chartres (1903) znajduje się napis tuszem piórkiem wykonany pośpiesznie: „Pankiewicz/Chartres”. Na odwrociu Portu w Concernaux II, (1908), widnieje napis piórkiem czarnym tuszem: „J. Pankiewicz 1908/ /Concerneaux", fot. 22, w obrazie Na tarasie - portret żony pojawia się napis ołówkiem ,...nieczytelne/ Espagne 1914-1919”, na odwrociu Węgórz̧a w Sanary (1926), ołówkiem naniesiono datę trudną do odczytania, prawdopodobnie: „1926”, na odwrociu Krajobrazu góraystego ₹ Potudniowej Franci, (1927) widnieje napis „77 paysage... nieczytelne” w obrazie Autoportret z.paletq z 1927 roku, na poprzecznej listwie drewnianego krosna czarnym tuszem lub atramentem napisano „Pankiewicz Le Mugel (la Ciotat) 1927”, a na odwrociu Portret kobiety (1928), znajduje się wykonany ołówkiem niezbyt czytelny napis, prawdopodobnie określający portretowaną: „Prochaskowa”. 
Sygnatura Pankiewicza wykazuje spore zróżnicowane nawet na przestrzeni dość krótkiego czasu. Sa jednak pewne elementy właściwe poszczególnym okresom. Nie mogą one jednak stanowić podstawy do orzekania o autentyczności dzieł, a jedynie w sposób ostrożny ją wspomagać.

\section{Summary}

\section{Some remarks on signatures in Józef Pankiewicz' oil paintings}

Signatures of oil paintings from all stylistic periods of Pankiewicz has been analysed. The artist put his signatures both in left and right corners and sometimes in other different positions in the painting. The lettering was evolving from static official style to more freely one and integrated within the composition. In the symbolic period in paintings in which the sizes had been changed by artist, there appeared two original signatures differing in character. Each period had some characteristic features of the signature. Yet the diversity of the style of letters used, gives no opportunity of certain attributions basing mainly on analysis of the signature, yet it can be supporting indicator. 


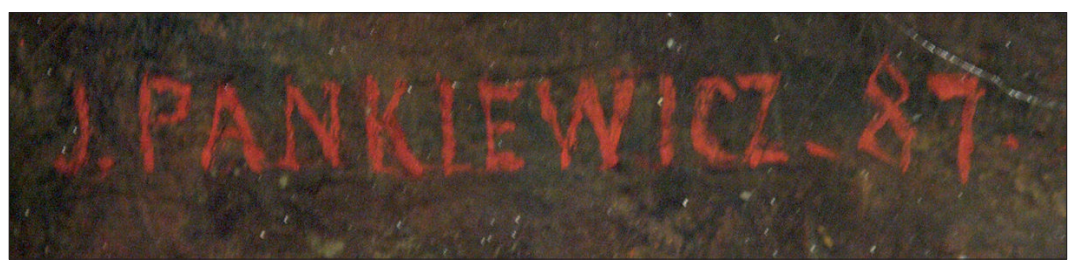

Fot. 1. Sygnatura, Żyd z koszem, 1887, MNW, fot. M. Wachowiak

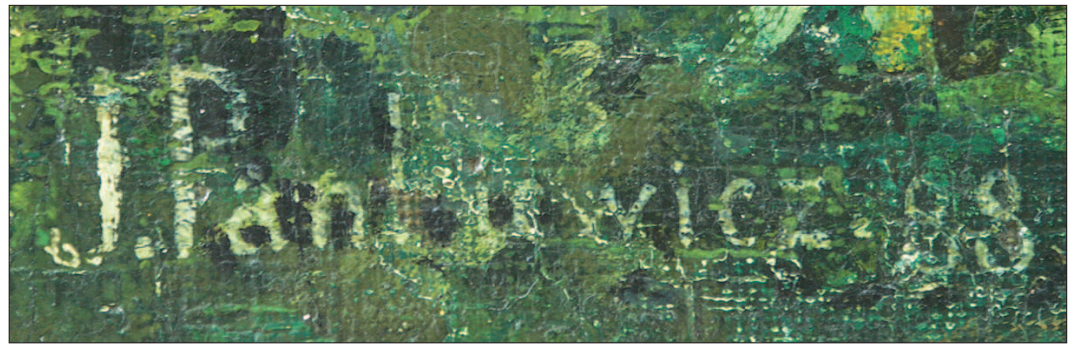

Fot. 2. Sygnatura, Targ za Żelazna Brama, 1888, MNP, fot. M. Wachowiak

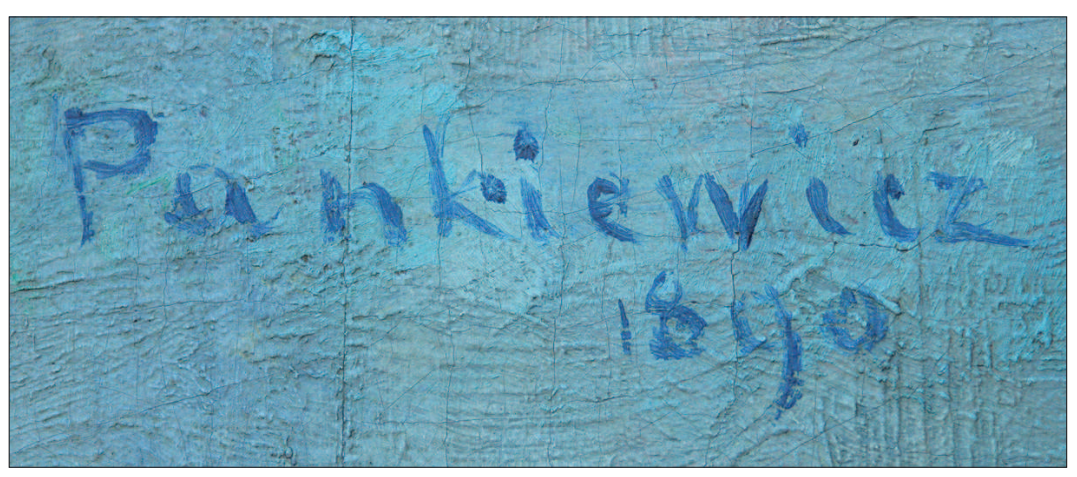

Fot. 3. Sygnatura, Targ na kwiaty, 1890, MNP, fot. M. Wachowiak

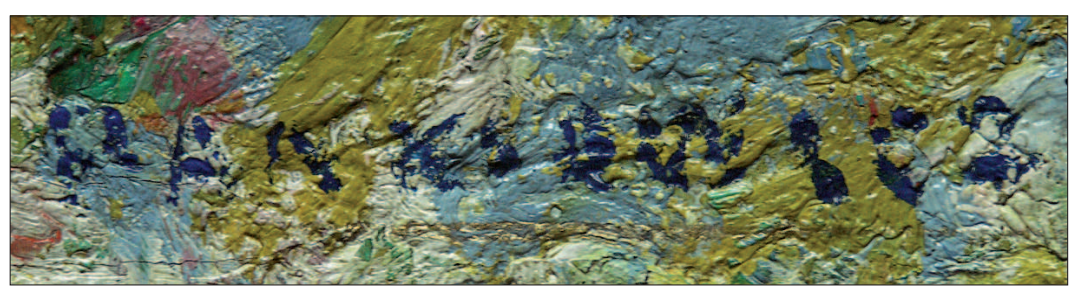

Fot. 4. Sygnatura, Lato, 1890, MŚK, fot. M. Wachowiak

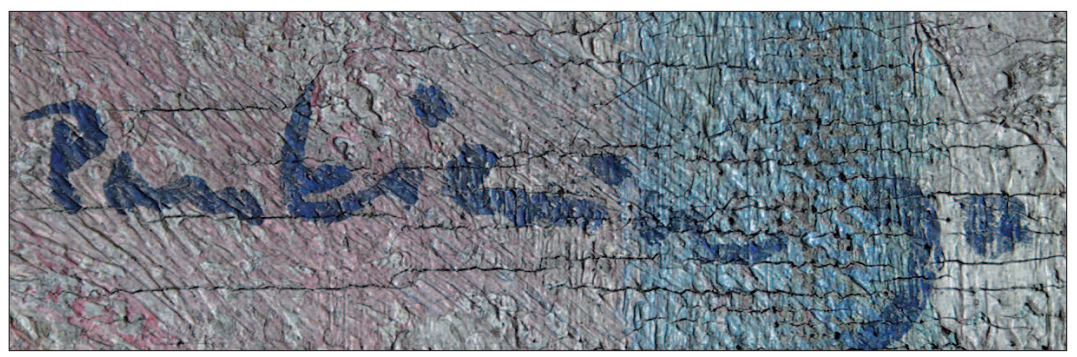

Fot. 5. Sygnatura, Droga w Kazimierzu, 1890, MSK, fot. M. Wachowiak 


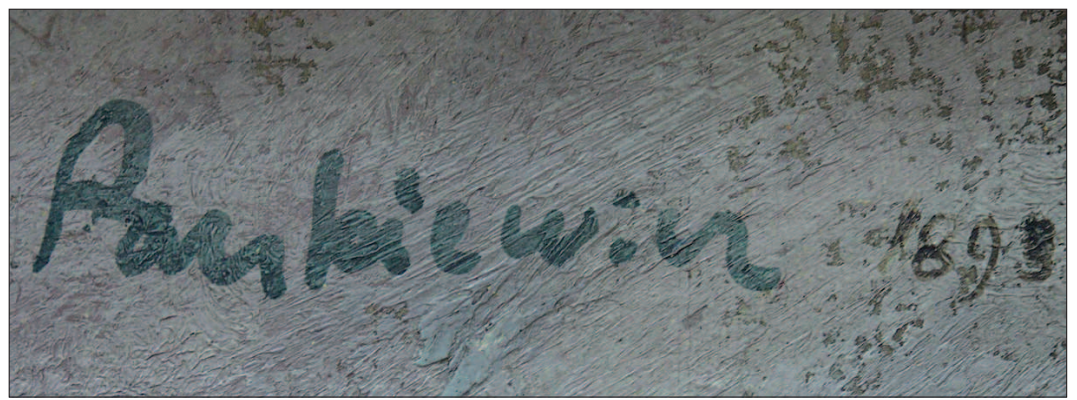

Fot. 6. Sygnatura, Portret kobiety, 1893, MNK, fot. M. Wachowiak

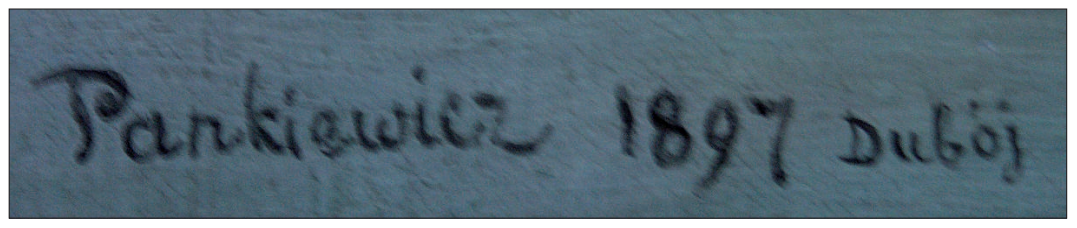

Fot. 7. Sygnatura, Park w Duboju, 1897, MNW, fot. M. Wachowiak
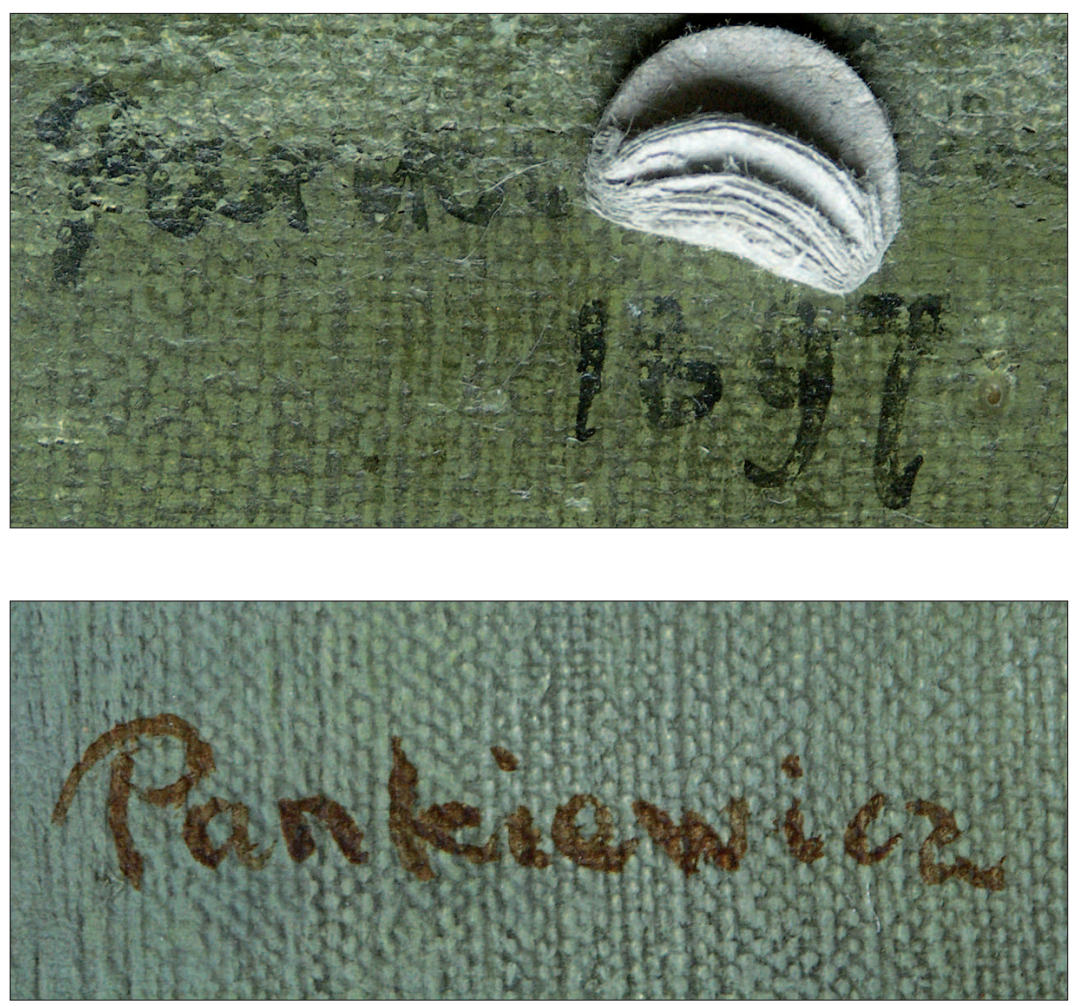

Fot. 8. 9. Sygnatura, Driewcrynka w czerwonej sukni, MNKi, 1897, u góry - sygnatura ukryta pod felcem ramy na górnej krajce, na dole - sygnatura na licu., fot. M. Wachowiak 


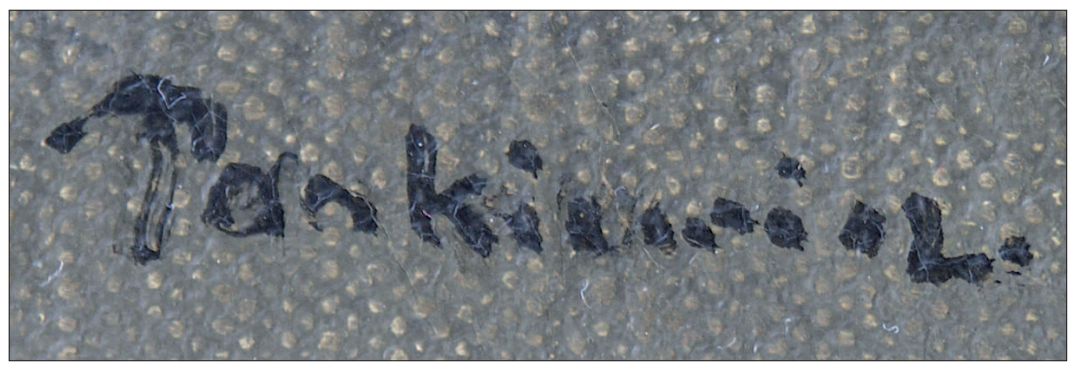

Fot. 10. Sygnatura, Portret wtasny, 1904, MNP, fot. M. Wachowiak

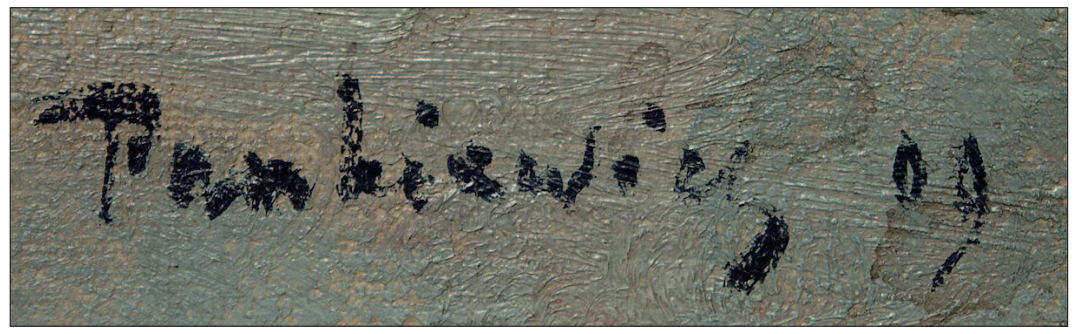

Fot. 11. Sygnatura, Martwa natura ₹ nożem, 1909, MNK, fot. M. Wachowiak

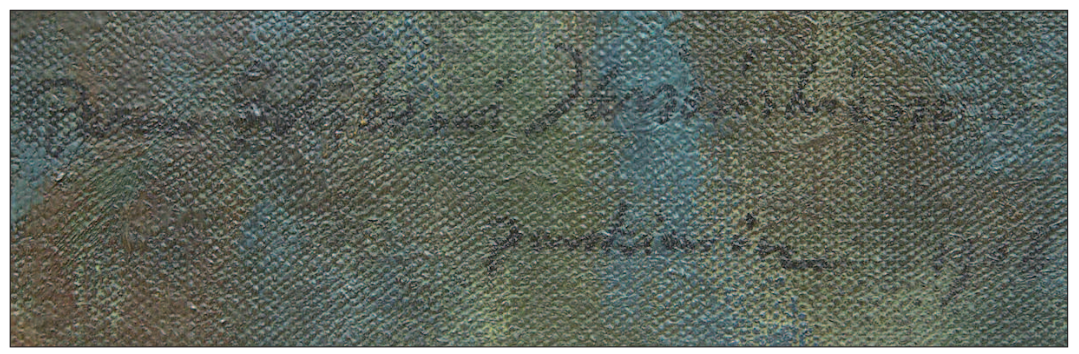

Fot. 12. Sygnatura i dedykacja, Portret Jasieńskiego, 1908, MNK, fot. M. Wachowiak

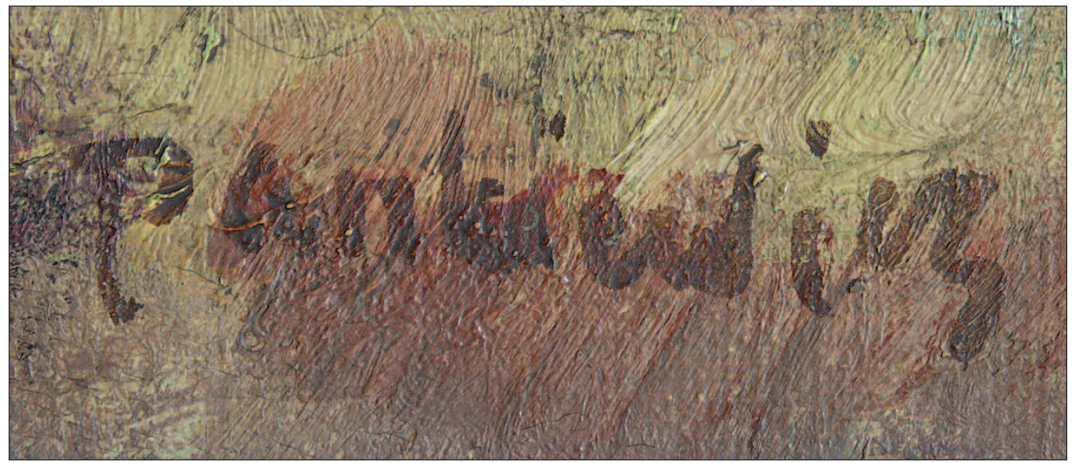

Fot. 13. Sygnatura, Snopy, 1912, MNKi, fot. M. Wachowiak 


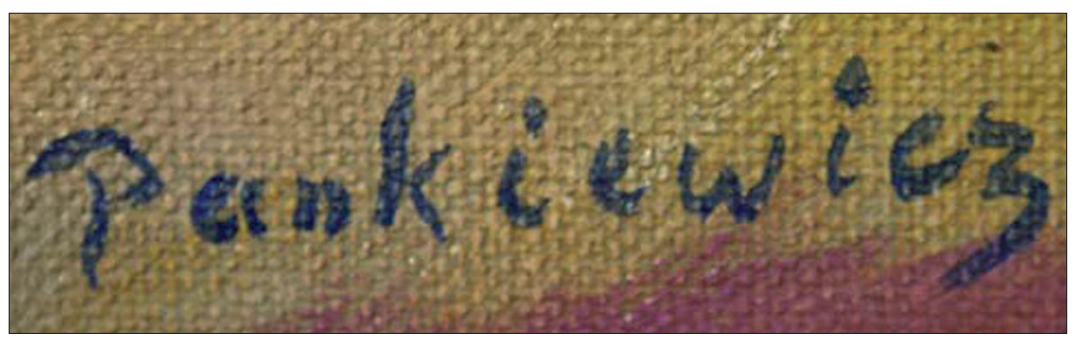

Fot. 14. Sygnatura, Pejzaż z San Rafael I, 1915-1916, wł. pryw., fot. M. Wachowiak

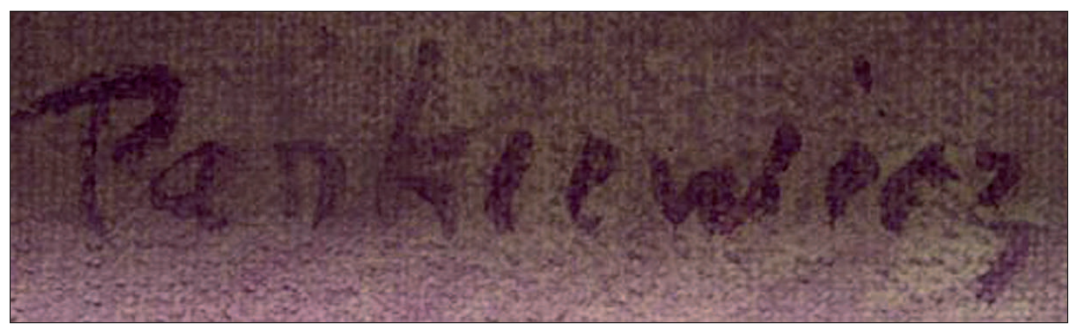

Fot. 15. Sygnatura, Martwa natura, 1916- 1918, MNW, fot. M. Wachowiak

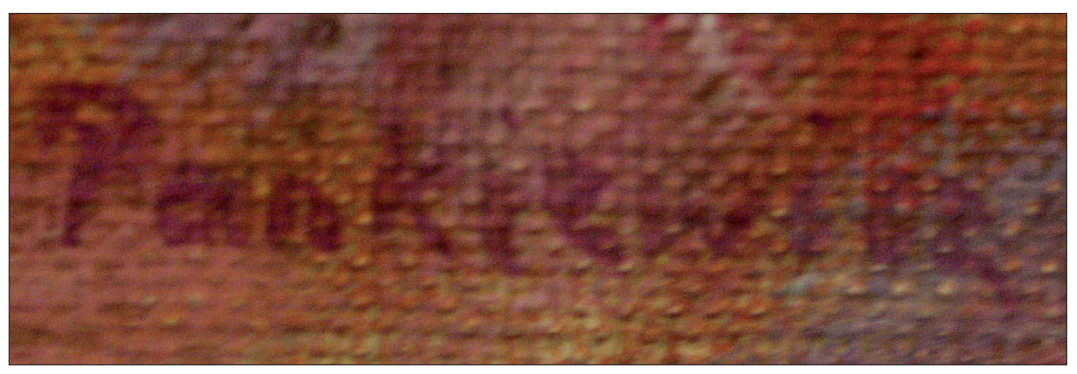

Fot. 16. Pejzaż z Saint-Tropez- Pinie, 1921, MNW, fot. M. Wachowiak

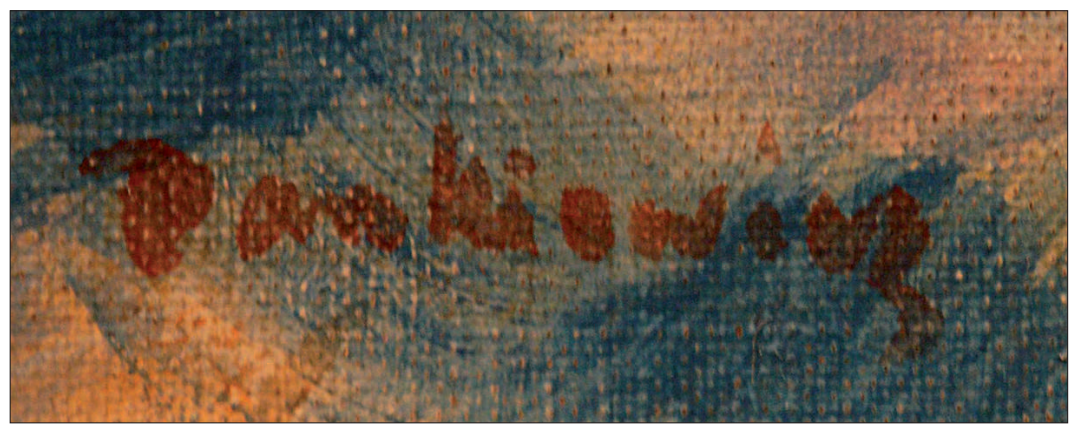

Fot. 17. Sygnatura, Anemony w dz̧banku, ok.1921, fot. M. Wachowiak 


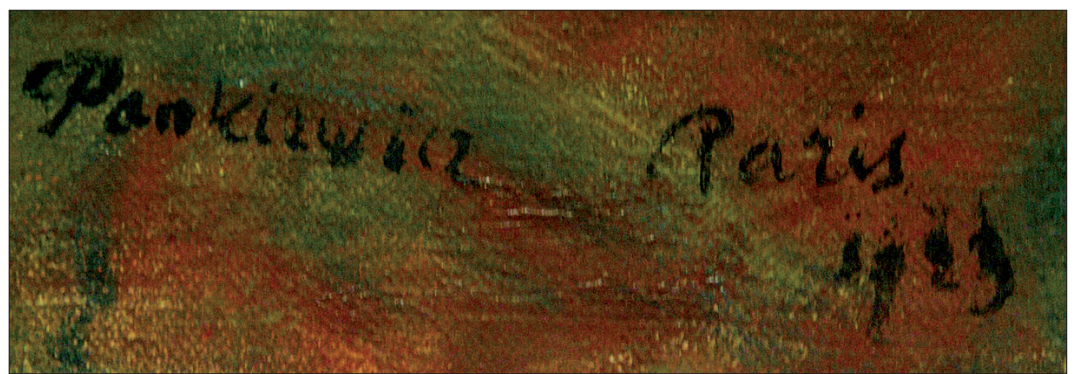

Fot. 18. Sygnatura, Akt na kanapie z różowa poduszka, 1923, wł. pryw., fot. M. Wachowiak

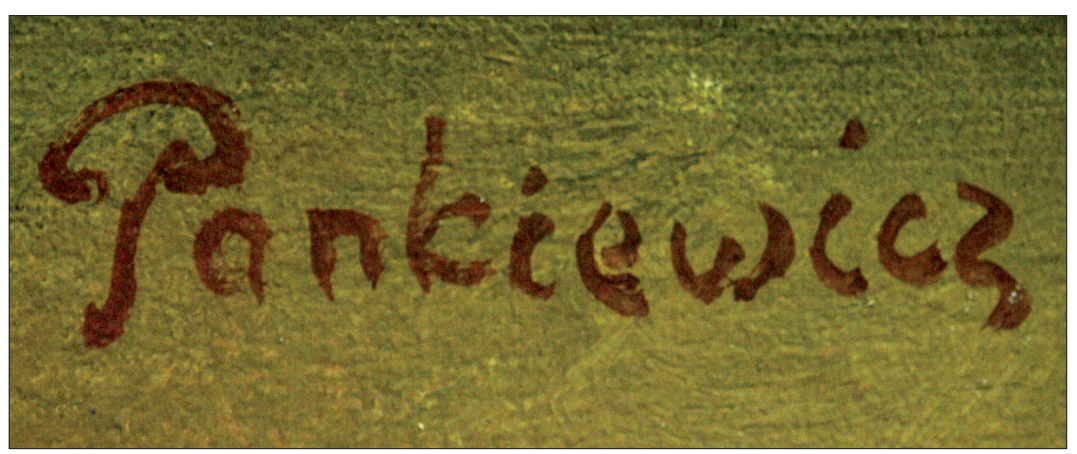

Fot. 19. Sygnatura, Róże w sælklanym wažnie i ksiażki, 1925, fot. M. Wachowiak

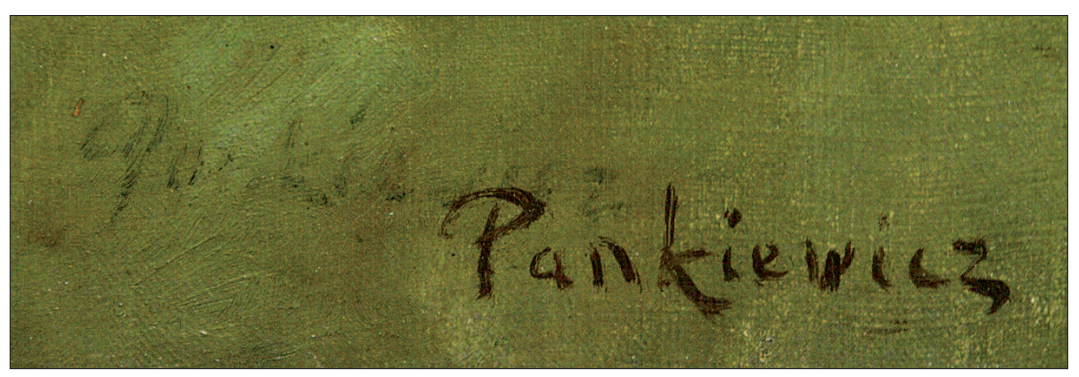

Fot. 20. Sygnatura, Akt kobiety siedzacej na krześle, 1925, fot. M. Wachowiak

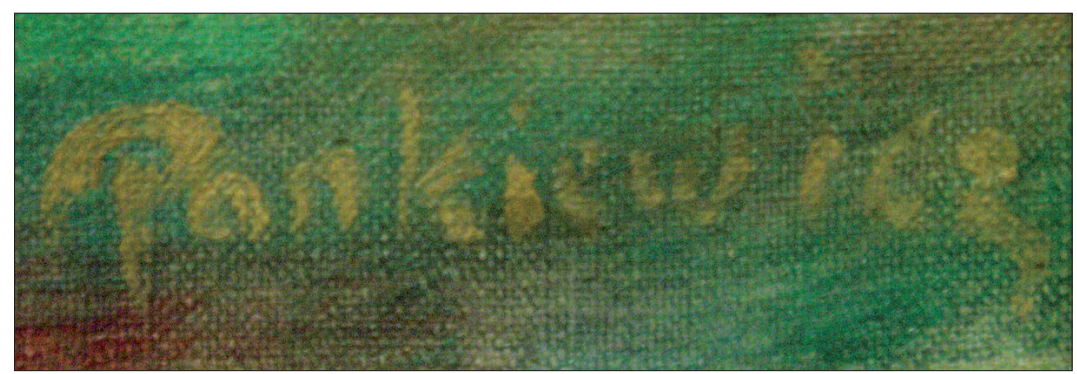

Fot. 21. Sygnatura, Pejzaż z Saint-Tropez - Pinie, 1921, MNW, fot. M. Wachowiak 


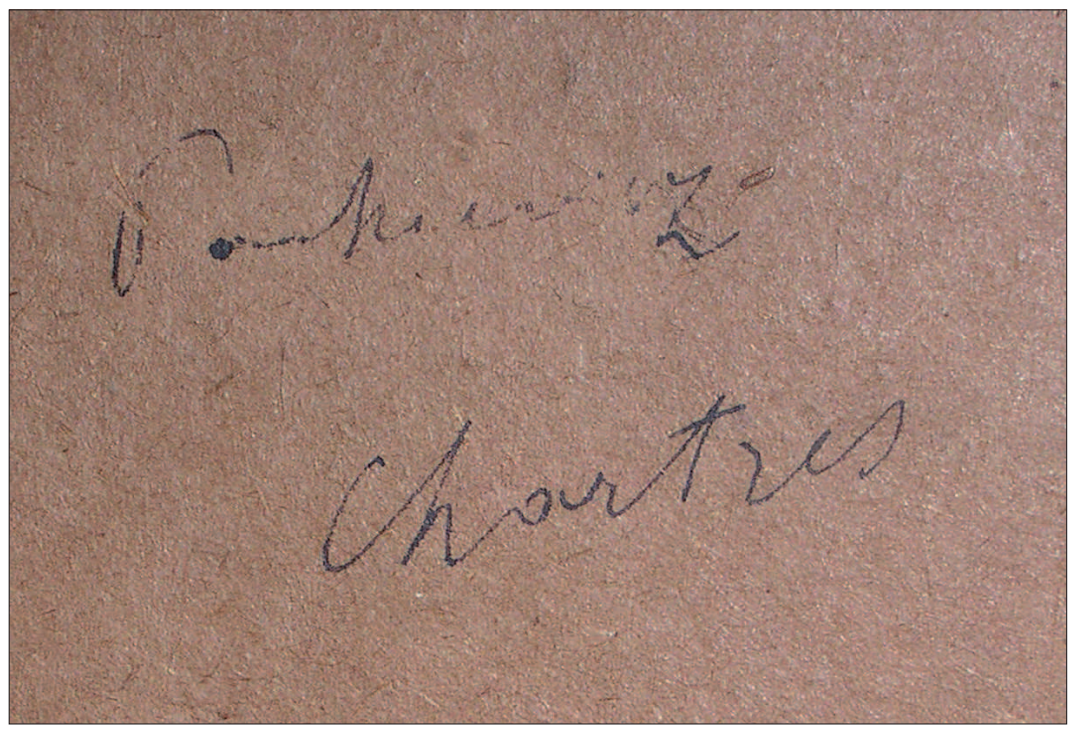

Fot. 22. Podpis piórkiem, odwrocie, Katedra w Chartres - szkic, MOT, 1903, fot. M. Wachowiak 